\title{
The human enteric coronaviruses
}

\author{
S. K. R. ClaRKE* \\ M.D., F.R.C.Path
}

E. O. CAUL ${ }^{*}$

F.I.M.L.S.

\author{
S. I. EGGLeSTONE** \\ Ph.D. \\ * Public Health Laboratory, Myrtle Road, Kingsdown, Bristol BS2 8EL, and \\ ** Public Health Laboratory, Church Lane, Heavitree, Exeter EX2 5AD
}

\begin{abstract}
Summary
A coronavirus was seen in the faeces from 15 $(4.2 \%)$ of 355 adults with diarrhoea and from 5 $(5.2 \%)$ of 96 adults without diarrhoea. Similar particles were seen in the faeces from $5(2.2 \%)$ of 227 children aged 1-14 years with gastroenteritis, but in none of those from 230 infants under one year of age with gastroenteritis.
\end{abstract}

There was no evidence that the coronavirus was responsible for any of 34 outbreaks of gastroenteritis, although it possibly caused diarrhoea in patients admitted to a psycho-geriatric unit. Excretion of the virus often continued for many months.

One strain was propagated in human embryo kidney monolayers and human embryo intestinal organ cultures, although serial passage could not be accomplished.

\section{Introduction}

Coronaviruses belong to a distinct virus family, the Coronaviridae (Tyrrell et al., 1978), the properties of which have been reviewed by McIntosh (1974). Until recently the only human strains of coronavirus known were those which infect the respiratory tract. However, coronaviruses have now been found in the faeces of patients in the U.K. with and without gastroenteritis (Caul, Paver and Clarke, 1975), and of people in South India (Mathan et al., 1975) and Australia (Moore et al., 1977; Schnagl et al., 1977). In fact many other members of the Coronaviridae have been found in the intestinal tract of other species, some of which have been shown to cause gastroenteritis (Table 1).

As a group, these viruses are extremely fastidious but most have been propagated, usually requiring either primary cell cultures or organ cultures for primary isolation.

Cultural problems have hindered the work with the human enteric coronavirus found in this laboratory; nevertheless, some progress has been made with its characterization. This paper summarizes the results obtained in studies of the morphology, propagation, morphogenesis and epidemiology of the human enteric coronavirus, and compares its intracellular development with that of the bovine enteric coronavirus in a similar intestinal organ culture system. Some of this work has already been reported (Caul and Clarke, 1975; Caul and Egglestone, 1977; Caul, Ashley and Egglestone, 1977, 1978; Bridger, Caul and Egglestone, 1978).

\section{Patients and methods}

Four groups of people were studied:

(1) Patients with sporadic gastroenteritis. Specimens of faeces from 812 patients with sporadic gastroenteritis had been submitted to the Bristol and Gloucester Public Health Laboratories for bacterial examination between February 1975 and December 1976.

(2) Normal subjects. Between January and November 1977 specimens of faeces were obtained from 96 healthy adult male waterworks employees for exclusion of typhoid carriage.

(3) Patients with Salmonella gastroenteritis. Specimens of faeces collected from 39 patients with gastroenteritis caused by $S$. agona.

(4) People involved in outbreaks of gastroenteritis. Between 1963 and 1976, 34 outbreaks of gastroenteritis were studied. These had occurred in various parts of the U.K. and in various types of closed or semi-closed community (Table 2). In all outbreaks, specimens of faeces were collected from patients with gastroenteritis, and in many outbreaks. they were collected also from contacts without gastroenteritis.

Follow-up specimens of faeces were collected from some subjects (with and without gastroenteritis) found to be excreting coronaviruses. Specimens of faeces from groups 1,2 and 3 were examined within a few days of collection, but the majority of those from outbreaks had been stored at $-70^{\circ} \mathrm{C}$ for up to 13 years.

Laboratory methods have been described elsewhere (Caul and Egglestone, 1977; Caul et al., 1978). 
TABLE 1. Coronaviruses which have been found in the intestinal tract of various species

\begin{tabular}{|c|c|c|c|}
\hline Virus & Host & Reference & $\begin{array}{l}\text { Proved as causing } \\
\text { gastroenteritis }\end{array}$ \\
\hline $\begin{array}{l}\text { Transmissible gastroenteritis } \\
\text { (TGE) virus }\end{array}$ & Pig & $\begin{array}{l}\text { Tajima, } 1970 \\
\text { Pensaert, Haelterman and Burnstein, 1970a } \\
\text { Pensaert, Haelterman and Hinsman, 1970b }\end{array}$ & Yes \\
\hline Transmissible enteritis (Bluecomb) virus & Turkey & Panigrahy, Naqi and Hall, 1973 & Yes \\
\hline Mouse hepatitis virus (MHV) & $\begin{array}{l}\text { Newborn } \\
\text { mouse }\end{array}$ & Broderson, Murphy and Hierholzer, 1976 & Yes \\
\hline Bovine enteric coronavirus & $\begin{array}{l}\text { Newborn } \\
\text { calf }\end{array}$ & $\begin{array}{l}\text { Stair et al., } 1972 \\
\text { Mebus } \text { et al., } 1973 \\
\text { Woode and Bridger, } 1975\end{array}$ & Yes \\
\hline Canine coronavirus (1-71) & Dog & Binn et al., 1975 & Yes \\
\hline Avian infectious bronchitis (AIB) virus & Fowl & Alexander and Gough, 1977 & No \\
\hline Equine enteric coronavirus & Foal & Bass and Sharpee, 1975 & No \\
\hline Human enteric coronavirus & Man & Caul et al., 1975 & No \\
\hline
\end{tabular}

TABLE 2. Outbreaks of gastroenteritis studied

\begin{tabular}{lccc}
\hline & \multicolumn{2}{c}{ Number of outbreaks } & Total no. of \\
\cline { 2 - 3 } Type of community & Tested & $\begin{array}{l}\text { Corona } \\
\text { positive* }\end{array}$ & $\begin{array}{c}\text { subjects } \\
\text { tested }\end{array}$ \\
\hline General hospital & 7 & 1 & 58 \\
Geriatric unit & 6 & 2 & 79 \\
Institution for ESN $\dagger$ & 4 & 2 & 47 \\
Hotel/Holiday camp & 2 & 2 & 48 \\
Services camp & 3 & 1 & 21 \\
School & 9 & 0 & 108 \\
Family & 3 & 0 & 8 \\
Total & 34 & 8 & 369 \\
\hline
\end{tabular}

* Coronavirus excreted by one or more patients or contacts.

† Educationally subnormal.

\section{Results \\ Morphology}

Coronavirus particles seen in deposits from faecal suspensions by electron microscopy were often present in large numbers (Fig. 1). The characteristic features of these virus particles were their pleomorphism, the large number of collapsed particles showing stain penetration with no obvious internal structure, and the widely spaced radiating surface projections giving rise to a solar corona appearance. These projections, $18-25 \mathrm{~nm}$ in length, had a spherical or tear-drop dilatation at the distal end and were attached to the particles by a thin rod-like stalk. In a minority of faecal specimens some particles had an additional $T$-shaped structure attached to the end of the projections (Caul and Egglestone, 1977). Purification by ammonium sulphate precipitation instead of ultracentrifugation resulted in a smaller proportion of collapsed particles indicating less apparent damage to the virus (Caul et al., 1978). The criteria for differentiating these virus particles from other cellular fringed bodies have been described by Caul et al. (1977). Submitochondrial particles, which are extremely rare in faeces, have a 9-10 $\mathrm{nm}$ fringe (Fig. 2).

\section{Virus propagation}

Emulsions of faecal specimens from fiftee patients shown to contain coronavirus particles electron microscopy were inoculated into primary human embryo kidney monolayers. The cultures were examined by indirect immunofluorescence using the patients' own convalescent serum and fluoroscein-conjugated anti-human globulin. Only one culture exhibited fluorescence. Intracellular development of this antigen is shown in Fig. 3a-c. Attempted passage using neat and diluted material from the positive culture was unsuccessful in cultures derived from several different human embryo kidneys.

The one faecal specimen which provided this evidence of growth was inoculated into human embryo intestinal organ cultures. Virus multiplication in this system was demonstrated by an increase in the number of extracellular virus particles 음 in the organ culture fluids, positive immuno- $D$ fluorescence, and the appearance in the columnar epithelial cells of ultrastructural changes charac- N teristic of coronavirus replication. Structures which may have represented viral nucleocapsids were also 0 seen (Caul and Egglestone, 1977). Further passage $\omega$ in organ cultures resulted in fewer coronavirus ${ }^{\circ}$ particles in the extracellular fluids. These may have 0 represented residual inoculum or the result of limited $\mathbb{D}$ virus replication. These cultures were not examined ? by indirect immunofluorescence or by electron 


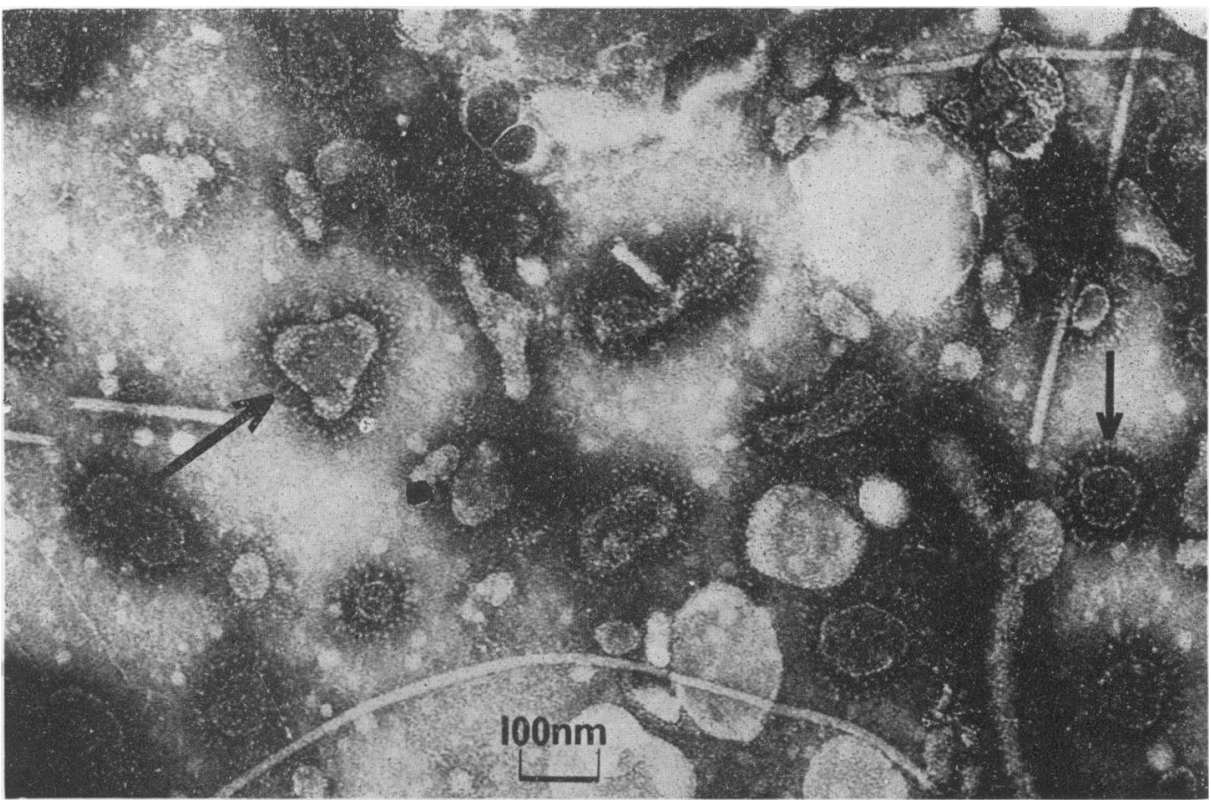

FIG. 1. Electron micrograph of faecal preparation negatively stained with $1.5 \%$ phosphotungstic acid. Arrows indicate a 'complete' (left) and an 'empty' (right) coronavirus particle.

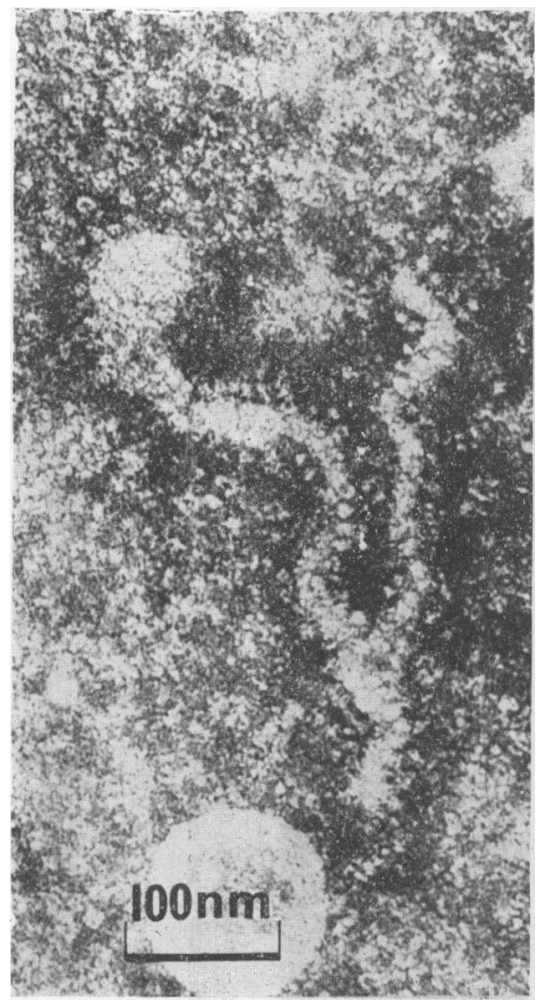

microscopy of thin sections. Emulsions of faecal specimens containing coronaviruses from 6 other patients were inoculated into human embryo intestinal organ culture. Electron microscopy of the medium and immunofluorescence of the cells gave negative results.

As this was the first ultrastructural study of the intracellular development of an enteric coronavirus in intestinal organ cultures, the changes were compared with those resulting from infection of a similar system with a known enteric coronavirus, i.e. bovine intestinal organ cultures infected with the bovine enteric coronavirus (Bridger et al., 1978) (Figs 4-6). Infected columnar epithelial cells from both the human and bovine cultures showed a loss of the microvillous border, virus particles in the cisternae of the smooth endoplasmic reticulum, a large membrane-bound virus-containing perinuclear vacuole with associated membranous cell organelles, and electron dense particles within cytoplasmic vesicles. Tubular inclusions with an electron dense core were seen in the human cells but not in the bovine cells. Budding from the cell surface was not seen in either system, and there was no evidence of nuclear involvement.

FIG. 2. Submitochondrial particle prepared from rat liver negatively stained with $1.5 \%$ phosphotungstic acid. 

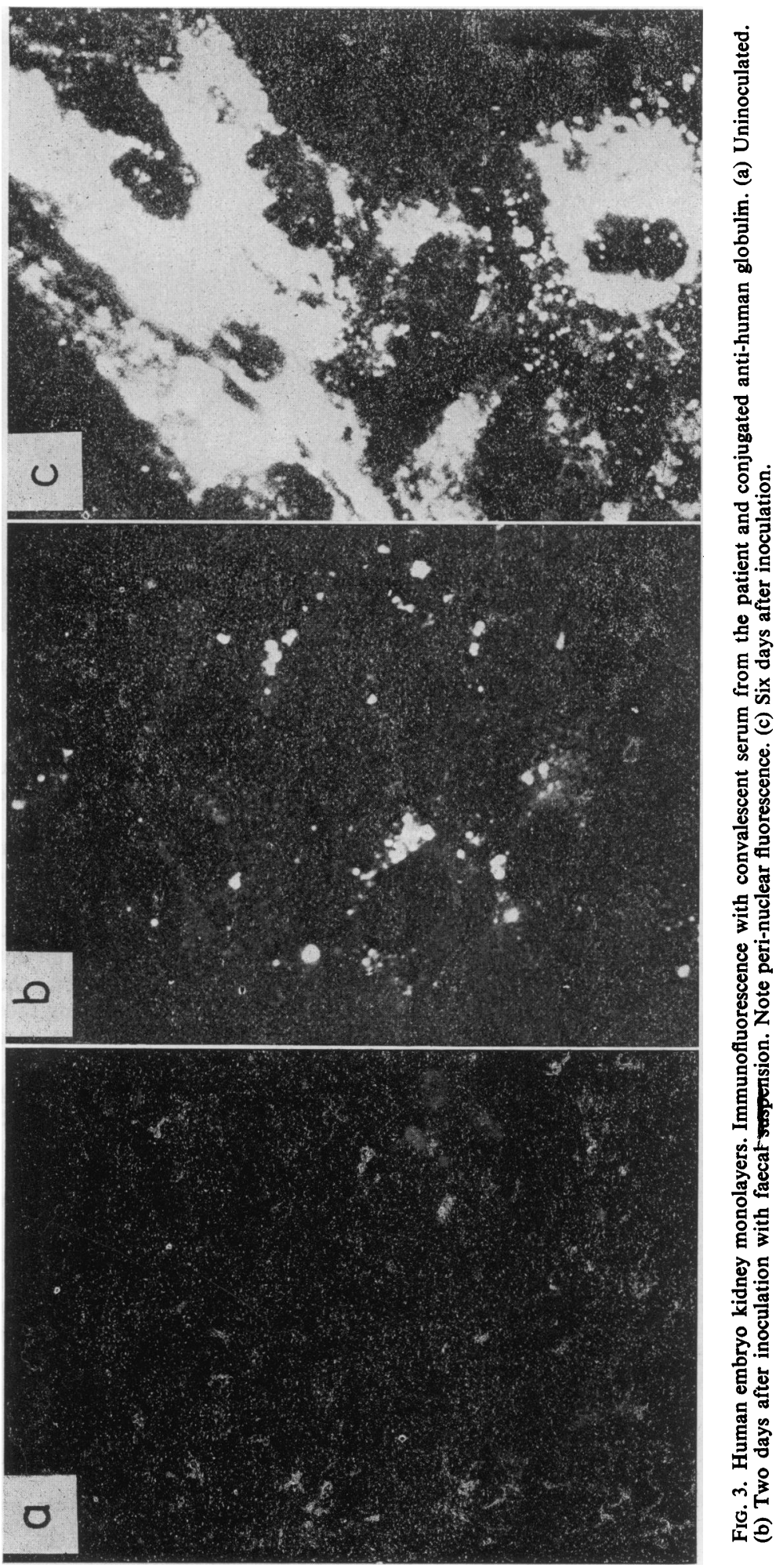


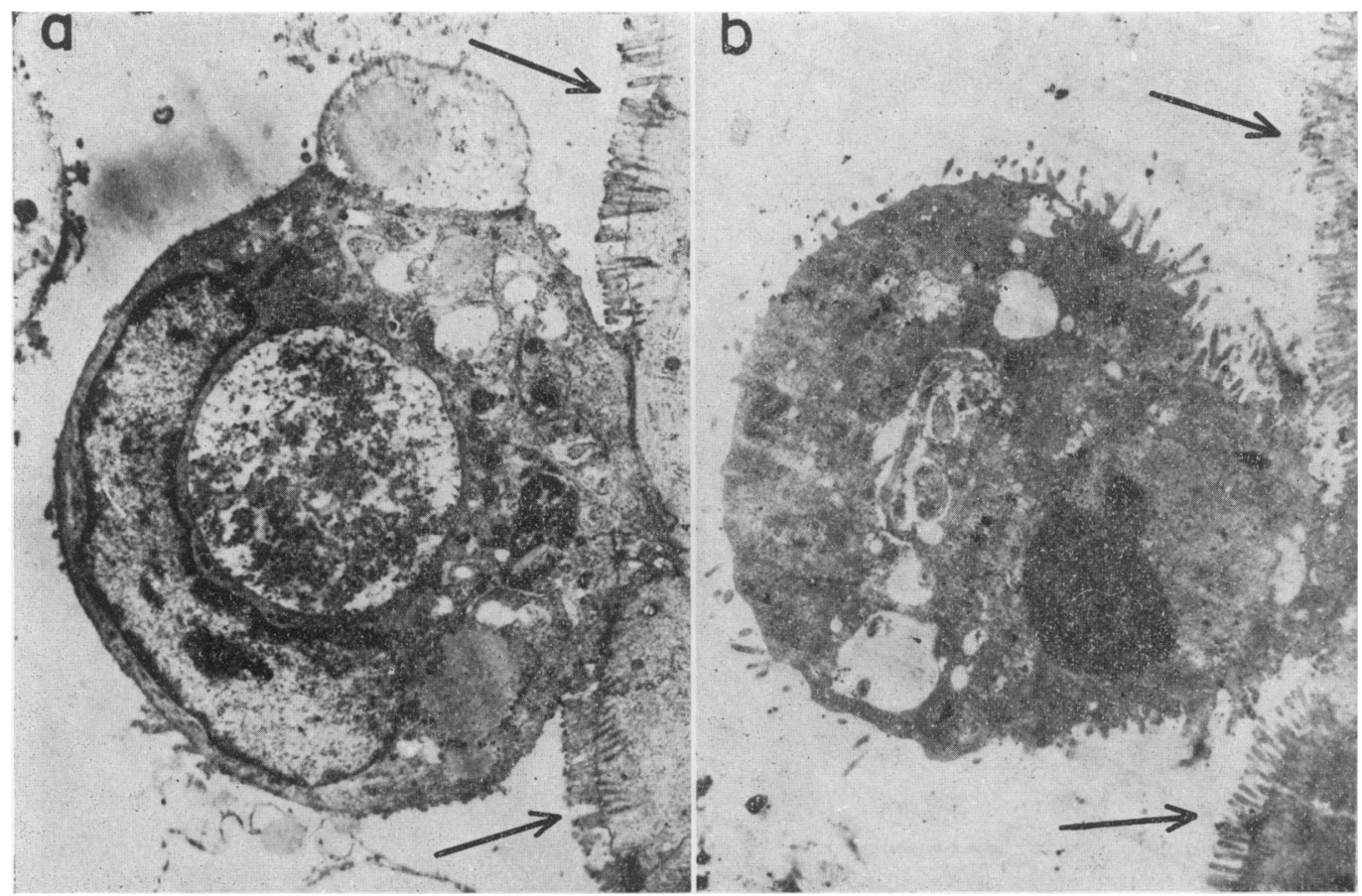

Fig. 4. Thin sections of virus-infected organ cultures. Extrusion of virus-infected mucosal cells in the midvillous region. Note the loss of the microvillous border from the infected cells, as compared with intact microvilli on adjacent uninfected cells (arrow). (a) Human embryo intestinal organ culture infected with human enteric coronavirus. (b) Bovine embryo intestinal organ culture infected with bovine enteric coronavirus.

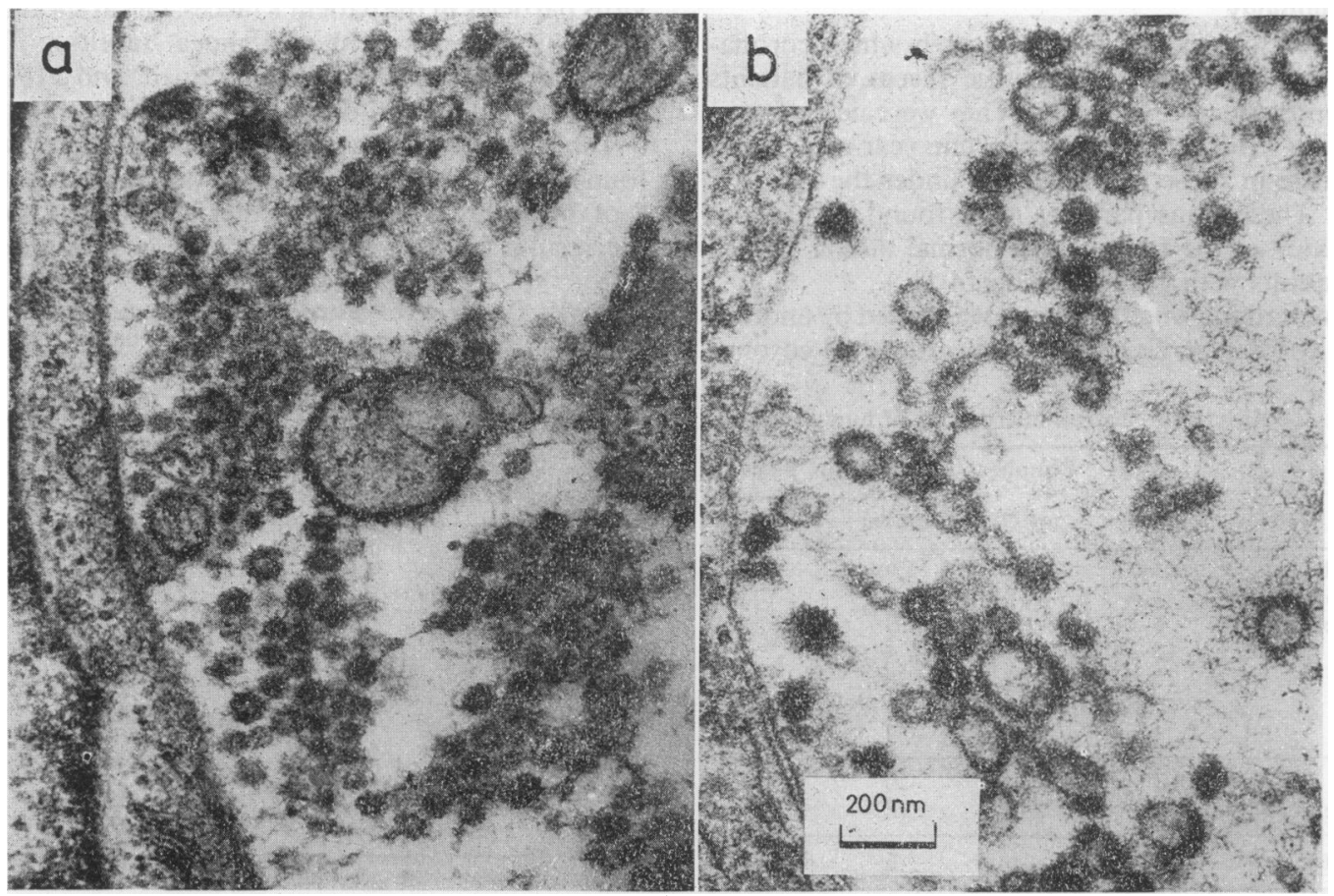

Fig. 5. Appearance of virus particles within a perinuclear vacuole. Degenerating membranous cell organelles are also present. (a) Human embryo intestinal organ culture infected with human enteric coronavirus. (b) Bovine embryo intestinal organ culture infected with bovine enteric coronavirus. 


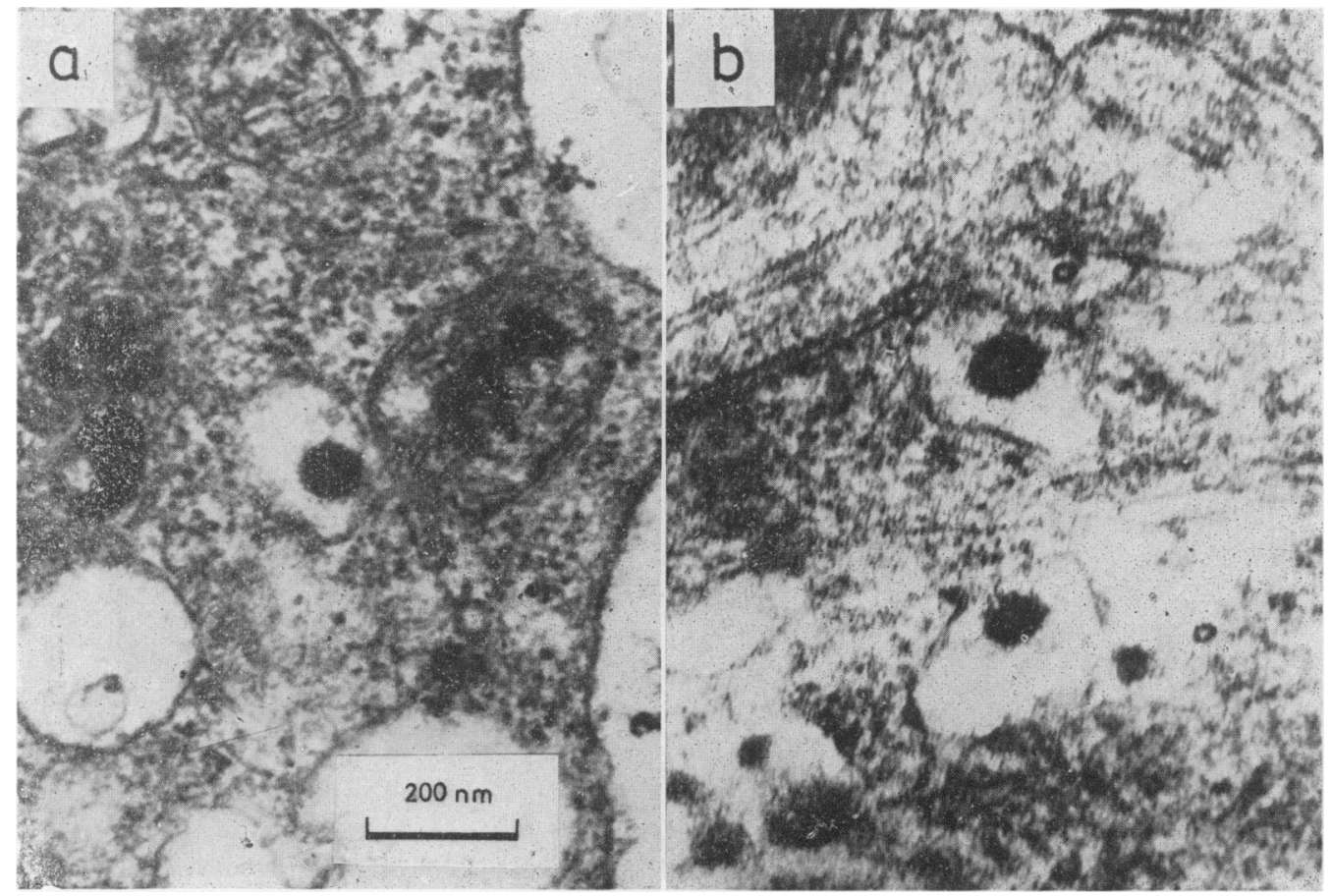

Fig. 6. Electron-dense virus particles in cytoplasmic vesicles. (a) Human organ culture infected with human coronavirus. (b) Bovine organ culture infected with bovine coronavirus.

\section{Epidemiology}

Table 3 shows the frequency with which coronavirus particles were seen in the faeces of patients with sporadic gastroenteritis. They were never found in faeces from infants less than one year of age and were rare in those from patients under the age of 5 years. These virus particles were found with equal frequency in the faeces from normal adults $(5.2 \%)$ as in adults with gastroenteritis $(4 \cdot 2 \%)$.

To determine whether diarrhoea caused by another agent could give rise to the appearance of corona-

TABLE 3. Results of electron microscopy of human faeces

\begin{tabular}{lcccc}
\hline & Age & Number & \multicolumn{2}{c}{ Coronavirus positive } \\
\cline { 5 - 6 } Group & (years) & tested & Number & $\%$ \\
\hline Sporadic & $<1$ & 230 & 0 & 0 \\
cases of & $1-4$ & 164 & 2 & $1 \cdot 2$ \\
gastroenteritis & $5-14$ & 63 & 3 & $4 \cdot 8$ \\
& $15-24$ & 62 & 4 & $6 \cdot 5$ \\
& $25-44$ & 144 & 6 & $4 \cdot 2$ \\
& $45-64$ & 78 & 1 & $1 \cdot 3$ \\
\hline Total & $>64$ & 71 & 4 & $5 \cdot 7$ \\
gastroenteritis & All ages & 812 & 20 & $2 \cdot 5$ \\
\hline No illness & Adults & 355 & 15 & $4 \cdot 2$ \\
\hline & Adults & 96 & 5 & $5 \cdot 2$ \\
\hline
\end{tabular}

virus particles in the patient's faeces, faecal specimens from 39 patients with diarrhoea resulting from infection with $S$. agona were examined, and $2(5 \cdot 1 \%)$ were seen to contain coronavirus particles.

Table 2 shows that coronavirus particles were found in the faeces of patients or healthy contacts in 8 of 34 outbreaks of gastroenteritis. Table 4 shows the results from these 8 outbreaks in more detail.

TABLE 4. Outbreaks of gastroenteritis in which coronaviruses were excreted by patients or contacts

\begin{tabular}{|c|c|c|c|c|}
\hline \multirow[b]{2}{*}{ Type of community } & \multicolumn{2}{|c|}{ Gastroenteritis } & \multicolumn{2}{|c|}{ No illness } \\
\hline & $\begin{array}{l}\text { No. } \\
\text { patients } \\
\text { tested }\end{array}$ & $\begin{array}{c}\text { No. } \\
\text { corona } \\
\text { positive }\end{array}$ & $\begin{array}{l}\text { No. } \\
\text { contacts } \\
\text { tested }\end{array}$ & $\begin{array}{c}\text { No. } \\
\text { corona } \\
\text { positive }\end{array}$ \\
\hline \multicolumn{5}{|l|}{ General hospital } \\
\hline Institution for $\mathrm{ESN}^{*}$ & 3 & 0 & 2 & 2 \\
\hline Institution for ESN* & 6 & 3 & 27 & 3 \\
\hline Geriatric unit & 1 & 1 & 5 & 0 \\
\hline Geriatric unit & 7 & $\mathbf{0}$ & 8 & 3 \\
\hline Hotel & 5 & 1 & 9 & 0 \\
\hline \multicolumn{5}{|l|}{ Holiday camp } \\
\hline Nursery nurses & 18 & 2 & 16 & 2 \\
\hline RAF apprentices & 9 & 2 & 0 & \\
\hline Total & 51 & 10 & 67 & 10 \\
\hline
\end{tabular}

* Educationally sub-normal. 
The virus was rarely found in more than a small proportion of affected patients. Overall it was found in $20 \%$ of cases and $15 \%$ of contacts.

A further study in a psycho-geriatric assessment ward of 16 patients is not included in Tables 2 or 4 . Over 2 years the majority of patients admitted to the ward developed diarrhoea soon after admission. In specimens collected over several weeks, it was found that 8 of 10 patients with diarrhoea were excreting coronaviruses as was one of 6 without. Thus $56 \%$ of the patients were excreting coronaviruses. One nurse with diarrhoea was found to be excreting the virus, but the results of the examination of faeces from 14 nurses without diarrhoea were negative.

Follow-up specimens of faeces were obtained from $2 \hat{2}$ of the people who had been shown to excrete coronaviruses, both sporadic cases of gastroenteritis and those involved in outbreaks. Coronavirus particles were no longer present in the faeces from 5 patients (specimens from 4 patients collected one to 14 weeks later, and one when re-tested after 4 years) but the remainder were still positive, 10 when re-tested 2-14 weeks later, and 7 when retested 6-17 months later.

\section{Discussion}

Human enteric coronavirus particles are unlikely to be confused with fringed cellular debris commonly found in faecal samples. The consistent solar corona appearance with projections approximately $20 \mathrm{~nm}$ long is totally different from the ill-defined fringes on non-viral material.

The projections on the human enteric coronavirus differ in shape from the classical petal-shaped structures described in avian infectious bronchitis (AIB) by Berry et al. (1964). Nevertheless differences in morphology of projections have been reported since by a number of workers for AIB virus (Estola and Weckström, 1967; Harkness and Bracewell, 1974) and for transmissible gastroenteritis (TGE) virus (Ritchie, 1976). Furthermore, the bovine enteric coronavirus possesses a double fringe (Caul and Egglestone, 1977). In view of these findings, the possession of classical petal-shaped projections should no longer be considered a prerequisite for coronavirus identification. The projections on the particles seen in the faeces of patients with tropical sprue by Mathan et al. (1975) were thin with a distal knob, like those of the virus described here, and some had T-shaped structures on the projections similar to those seen by the present authors. The nature of this additional structure remains to be clarified, but morphologically it resembles the IgA molecule described by Munn, Feinstein and Munro (1971).

The morphology of the human enteric coronavirus in faeces was more easily altered by ultracentrifugation than that of the same virus propagated in organ culture or other coronaviruses propagated in culture. After ultracentrifugation of the human virus from faeces, particles with few projections were not uncommon, and many had collapsed and showed stain penetration, indicating lack of a rigid internal component. This was not observed in similarly processed human faecal virus propagated in organ culture.

The infectivity of one strain of the virus in faeces was shown by its propagation in human intestinal organ culture and human embryo kidney cell cultures. The intracellular development of this virus in columnar epithelial cells was similar to that of a strain of bovine enteric coronavirus (Bridger et al., 1978) and other coronaviruses (McIntosh, 1974). Like other recently described human faecal viruses such as rotaviruses and astroviruses, the human enteric coronavirus is proving difficult to adapt to growth in cell or organ culture.

The human enteric coronavirus has not yet been proved as causing gastroenteritis, although this might be expected in view of the proved pathogenicity of TGE virus and the bovine enteric coronavirus. Since the human virus is excreted for such long periods, it is not surprising that it may be found in the faeces of some normal adults. It is difficult, therefore, to prove its pathogenicity by comparing its incidence in patients with gastroenteritis with that in contacts without symptoms. No evidence was obtained that the virus caused outbreaks of gastroenteritis, except in the psychogeriatric unit, where it appeared that patients acquired the coronavirus and diarrhoea soon after admission; even so, it was not possible to say that the virus was causing the diarrhoea. There was some evidence to indicate that infection with the coronavirus could result in prolonged diarrhoea, but more work is needed to establish this association.

Several of the patients found by the authors to be excreting coronaviruses had come from developing countries, or lived in an environment in this country where there was greater opportunity for faecal-oral spread, such as institutions for the mentally subnormal or psycho-geriatric units. This finding suggests that spread is by the faecal-oral route, but that the virus is relatively uninfectious, perhaps a very large number of virus particles being necessary to establish infection.

Mathan et al. (1975) in South India have found faecal coronaviruses in a large proportion of the 'normal' population (almost all of whom have tropical enteropathy) and an even higher proportion of those suffering from epidemic sprue. Electron microscopy of thin sections of intestinal biopsies from patients with tropical sprue showed virus-like 
particles in vesicles and in the cisternae of the smooth endoplasmic reticulum of damaged crypt cells (personal communication). These ultrastructural changes were similar to those observed in intestinal organ cultures infected with a strain of the human enteric coronavirus (Caul and Egglestone, 1977).

Chronic infection occurs with other coronaviruses - chronic excretion of AIB virus by fowls has been described by Alexander and Gough (1977) as has chronic infection of mice with murine hepatitis virus (MHV).

The observation of a large proportion of 'empty' particles in human faeces by electron microscopy suggests that the majority of the virus particles produced are defective. This might result in a lowgrade infection that persists. In such a situation one would not expect to find many cells where large numbers of 'complete' virus particles are being produced. The appearance of cells from intestinal biopsies seen by Mathan supports this. Persistent excretion of the human coronavirus was found in the present study and by Mathan et al. (1975). Further work is needed to see whether there is any relation between persistent infection and chronic intestinal pathology.

\section{Acknowledgments}

We would like to thank Mr C. R. Ashley, Drs J. C. Bridger and A. P. C. H. Roome for help with these studies. Some of the specimens from outbreaks of gastroenteritis were collected by the Public Health Laboratory Service Working Party on Non-bacterial Gastroenteritis.

\section{References}

Alexander, D.J. \& Gough, R.E. (1977) Isolation of avian infectious bronchitis virus from experimentally infected chickens. Research in Veterinary Science, 23, 344.

Bass, E.P. \& SharpeE, R.L. (1975) Coronavirus and gastroenteritis in foals. Lancet, ii, 822.

Berry, D.M., Cruickshank, J.G., Chu, H.P. \& Wells, R.J.H. (1964) The structure of infectious bronchitis virus. Virology, 23, 403.

Binn, L.N., Lazar, E.C., Keenan, K.P., Huxsoll, D.L., Marchwicki, R.H. \& Strano, A.J. (1975) Recovery and characterization of a coronavirus from military dogs with diarrhea. In: Proceedings of the 78th Annual Meeting, US Animal Health Association, Roanoke Va., October 1974, p. 359.

Bridger, J.C., Caul, E.O. \& Egglestone, S.I. (1978) Replication of an enteric bovine coronavirus in intestinal organ cultures. Archives of Virology, 57, 43.

Broderson, J.R., MurPhy, F.A. \& Hierholzer, J.C. (1976) Lethal enteritis in infant mice caused by mouse hepatitis virus. Laboratory Animal Science, 26, 824.

Caul, E.O., Ashley, C.R. \& Egglestone, S.I. (1977) Recognition of human enteric coronaviruses by electron microscopy. Medical Laboratory Science, 34, 259.

Caul, E.O., Ashley, C.R. \& Egglestone, S.I. (1978) An improved method for the routine identification of faecal viruses using ammonium sulphate precipitation. FEMS Microbiology Letters, 4, 1.

Caul, E.O. \& Clarke, S.K.R. (1975) Coronavirus propagated from patient with non-bacterial gastroenteritis. Lancet, ii, 953.

CAul, E.O. \& Egglestone, S.I. (1977) Further studies on human enteric coronaviruses. Archives of Virology, 54, 107.

Caul, E.O., Paver, W.K. \& Clarke, S.K.R. (1975) Coronavirus particles in faeces from patients with gastroenteritis. Lancet, i, 1192.

EstOLA, T. \& WeCKSTRÖM, P. (1967) Electron microscopy of infectious bronchitis virus. Annales medicinae experimentalis et biologiae fenniae, 45, 30 .

HARKNess, J.W. \& BRACEWELl, C.D. (1974) Morphological variation among avian infectious bronchitis virus strains. Research in Veterinary Science, 16, 128.

Mathan, M., Mathan, V.I., Swaminathan, S.P., Yesudoss, S. \& BAKER, S.J. (1975) Pleomorphic virus-like particles in human faeces. Lancet, i, 1068.

MCINTOSH, K. (1974) Coronaviruses: a comparative review. Current Topics in Microbiology and Immunology, 63, 85.

Mebus, C.A., Stair, E.L., Rhodes, M.B. \& Twiehaus, M.J. (1973) Neonatal calf diarrhea: propagation, attenuation and characteristics of a coronavirus-like agent. American Journal of Veterinary Research, 34, 145.

Moore, B., Lee, P., Hewish, M., Dixon, B. \& Mukherjee, T. (1977) Coronaviruses in training centre for intellectually retarded. Lancet, i, 261.

Munn, E.A., Feinstein, A. \& Munro, A.J. (1971) Electron microscope examination of free $\operatorname{IgA}$ molecules and of their complexes with antigen. Nature. London, 231, 527.

Panigrahy, B., NaqI, S.A. \& Hall, C.F. (1973) Isolation and characterization of viruses associated with transmissible enteritis (Bluecomb) of turkeys. Avian Diseases, 17, 430.

Pensaert, M., Haelterman, E.O. \& Burnstein, T. (1970) Transmissible gastroenteritis of swine: virus-intestinal cell interactions. I. Immunofluorescence, histopathology and virus production in the small intestine through the course of infection. Archiv für die gesamte Virusforschung, 31, 321.

Pensaert, M., Haelterman, E.O. \& Hinsman, E.J. (1970) Transmissible gastroenteritis of swine: virus-intestinal cell interactions. II. Electron microscopy of the epithelium in isolated jejunal loops. Archiv für die gesamte Virusforschung, 31, 335.

Ritchie, A.E. (1976) Morphology of TGE virus characteristic particles and their antigen-antibody complexes. In: Proceedings of the 4th International Congress of the International Pig Veterinary Society, Ames, Iowa (unpublished).

Schnagl, R.D., Holmes, I.H., Moore, B., Lee, P., DickinSON-JoNes, F. \& GuST, I.D. (1977) An extensive rotavirus outbreak in aboriginal infants in Central Australia. Medical Journal of Australia, 1, 259.

Stair, E.L., Rhodes, M.B., White, R.G. \& Mebus, C.A. (1972) Neonatal calf diarrhea: purification and electron microscopy of a coronavirus-like agent. American Journal of Veterinary Research, 33, 1147.

TAJima, M. (1970) Morphology of transmissible gastroenteritis virus of pigs. A possible member of coronaviruses. Archiv für die gesamte Virusforschung, 29, 105.

TyrRell, D.A.J., AleXANDER, D.J., Almeida, J.D., Cunningham, C.H., Easterday, B.C., Garwes, D.J., Hierholzer, J.C., Kapikian, A., Macnaughton, M.R. \& McIntosh, K. (1978) Coronaviridae: Second report. Intervirology, 10, 321.

WOODE, G.N. \& BRIDGER, J.C. (1975) Viral enteritis of calves. Veterinary Record, 96, 85. 